$\underline{\text { Review Article }}$

\title{
PHARMACEUTICAL WORLD OF PERMEATION ENHANCERS
}

\author{
MANISH KUMAR, DEEPAK PRASHAR* \\ Department of Pharmacy, LR Institute of Pharmacy, Jabeli-Kyar Solan (HP), India \\ Email: prashardeepak99@yahoo.in
}

Received: 06 May 2021, Revised and Accepted: 04 Jul 2021

\begin{abstract}
The drugs with poor solubility results in delayed absorption which consequently affects the bioavailability. There are many drugs which are having good therapeutic value but not used commercially because of this reason. The permeation enhancers are therefore being utilized to counter this problem. There are many such synthetic and natural materials which have the ability to enhance the drug permeation rate. The essential oils, alcohols, terpenes, azoles and many other chemical derivatives have the capability to be used for permeation enhancer. The present review work suggested the role of permeation enhancer in the pharmaceutical world.
\end{abstract}

Keywords: Permeation enhancer, Essential oils, Drugs, Natural, Synthetic

(c) 2021 The Authors. Published by Innovare Academic Sciences Pvt Ltd. This is an open access article under the CC BY license (https://creativecommons.org/licenses/by/4.0/) DOI: https://dx.doi.org/10.22159/ijcpr.2021v13i5.1894 Journal homepage: https://innovareacademics.in/journals/index.php/ijcpr

\section{INTRODUCTION}

Nature has provided the humanities with the wide range of natural substances which can be used in a number of ways. In this context the pharmaceutical market and research too are in one way or the other dependent on nature. The herbal, as well as the biological products, can be utilized in this perspective. The numerous drugs are there which lack its usage and difficult to be formulated because of the poor permeability [1-8]. This hitch has confined the use of many drugs, which is potentially and therapeutically very active. To counter this problem the researchers have tried to incorporate the permeation enhancers. These permeation enhancers can be of natural origin or semi-synthetic or even synthetic too. The large numbers of researchers all over the globe are working hard to bring out the best permeation enhancer with wide compatibility [9-20] The present work tries to focus on the natural permeation enhancer used in the pharmaceutical world.

Superlative properties of permeation enhancer [21]

1. Biocompatible with no toxicity induction properties (least or no chances of toxicity).

2. There should not be biocompatibility issues with incorporated medicaments.
3. Possesses good solvent properties with economical nature.

4. Must have sustainable, reproducible and rapid action.

5. Minimum adverse reaction with better therapeutic enhancement.

6. Should be physically and chemically inert with no organoleptic involvement with active ingredients and formulations.

7. Should not causes leakage of body fluid or endogenous material with unidirectional flow properties.

8. Must have the capacity to be tested in vitro for better results of final formulations.

\section{Mechanism of permeation enhancers}

The mechanism of action of permeation enhancer depends upon the technique through which it works. The permeation enhancers are operated though natural, drug vehicle based, chemical and physical. The natural permeation enhancers like terpenes and essential oils works through partition coefficient, diffusion coefficient, drug solubility, lipid extraction, molecular orientation and macroscopic barrier and perturbation [22, 23]. The drug vehicle-based technique is activated through enhancer's interaction with the stratum corneum and initiate permeation.

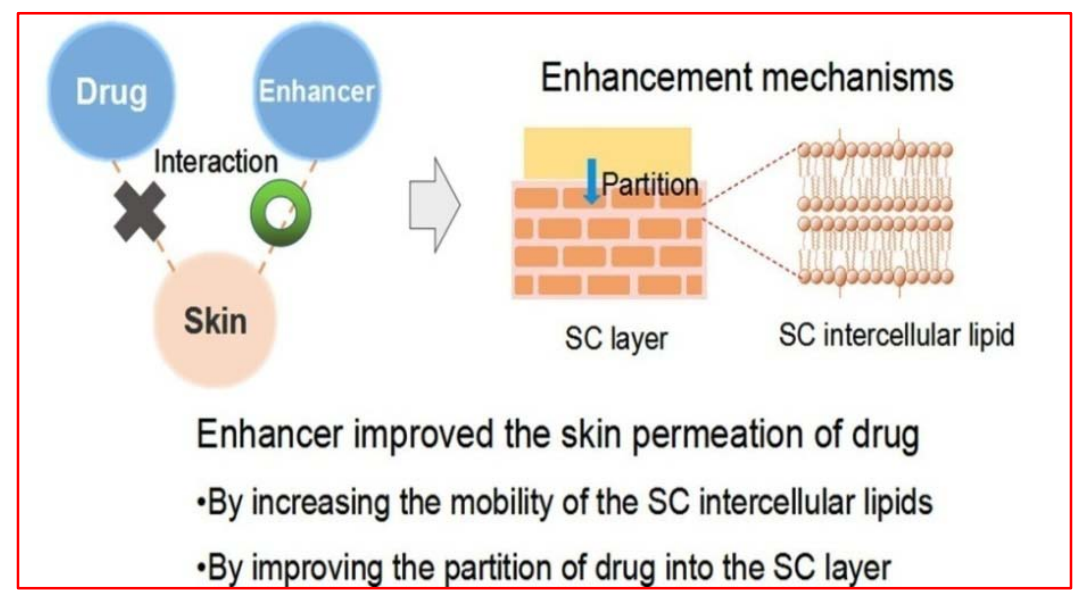

Fig. 1: Mechanism of action permeation enhancer [22] 
In chemical permeation enhancers one among the three ways worked out like chemical interaction with intracellular protein, by improving partition of drug in stratum corneum, or by disruption of highly ordered lipids of stratum corneum. In case of the physical permeation enhancement technique the magnetic separation, physical separation and ultrasonic wave are utilized (iontophoresis, sonophoresis, magnatophoresis etc).

\section{Categories of permeation enhancers}

Table 1: Pharmaceutically available permeation enhancers [24]

\begin{tabular}{|c|c|c|c|}
\hline S. No. & Permeation enhancers category & Examples & Techniques of permeation enhancers \\
\hline 1. & Terpenes & $\begin{array}{ll}\text { - } & \text { Nerolidol } \\
\text { - } & \text { Farnesol } \\
\text { - } & \text { Carvone } \\
\text { - } & \text { Menthone } \\
\text { - Linalool } \\
\text { - Limonine }\end{array}$ & Natural Permeation enhancers \\
\hline 2. & Essential oils & $\begin{array}{ll}\text { - } & \text { Basil Oil } \\
\text { - } & \text { Neem Oil } \\
\text { - } & \text { Eucalyptus Oil } \\
\text { - } & \text { Soyabean Oil } \\
\text { - } & \text { Olive Oil } \\
\text { - } & \text { Groundnut Oil } \\
\text { - } & \text { Corn Oil } \\
\text { - Jojoba Oil }\end{array}$ & Natural Permeation enhancers \\
\hline 3. & Sulfoxides & $\begin{array}{l}\text { - Dimethyl Sulfoxide } \\
\text { - Dimethyl Acetamide }\end{array}$ & Chemical Enhancers \\
\hline 4. & Glycols & $\begin{array}{l}\text { - Propylene Glycol } \\
\text { - Polyethylene Glycol } 400\end{array}$ & Chemical Enhancers \\
\hline 5. & Pyrrolidones & $\begin{array}{ll}\text { - } & \text { 2-Pyrrolidone } \\
\text { - } & \text { 1-Lauryl-2-Pyrrolidone } \\
\text { - } & \text { N-Methyl-2-Pyrrolidone }\end{array}$ & Chemical Enhancers \\
\hline 6. & Alcohols & $\begin{array}{l}\text { - Ethanol } \\
\text { - 1-Hexanol } \\
\text { - 1-Decanol } \\
\text { - 1-Octanol } \\
\text { - Lauryl Alcohol } \\
\text { - Linolenyl Alcohol }\end{array}$ & Chemical Enhancers \\
\hline 7. & Azones & - 1-Alkyl-Cycloalkanones & Chemical Enhancers \\
\hline 8. & Fatty acids and its esters & $\begin{array}{ll}\text { - } & \text { Oleic Acid } \\
\text { - } & \text { Lauric Acid } \\
\text { - } & \text { Capric Acid } \\
\text { - } & \text { Butyl Acetate } \\
\text { - } & \text { Isopropyl Myristate } \\
\text { - } & \text { Cetyl Lactate }\end{array}$ & Chemical Enhancers \\
\hline 9. & Urea derivatives & $\begin{array}{l}\text { - Urea } \\
\text { - 1-Dodecylurea } \\
\text { - 1-Dodecyl-3-Methyl Urea } \\
\text { - 1-Dodecyl-3-Methyl Thiourea }\end{array}$ & Chemical Enhancers \\
\hline 10. & Surfactants & $\begin{array}{l}\text { - Cetyl Trimethyl Ammonium Bromide } \\
\text { - Sorbiton Mono Palmitate }\end{array}$ & Chemical Enhancers \\
\hline
\end{tabular}

\section{Advancement In permeation enhancers}

Omar et al., 2019 developed the topical gel containing lignocaine for substituting the painful parenteral route. Transfersomal lignocaine was being prepared using PAMAM G3 dendrimer as permeation enhancer. The final formulation showed the enhancement in the local anesthetic activity by 1.62 folds [25].

Loganathan et al., 2001 studied the effect of permeation enhancers on the release of flurbiprofen from gel formulation. The DSMO and SLS were used as the permeation enhancers in different concentration. The $15 \%$ DSMO containing formulation showed the best results in vitro studied, while the anti inflammatory activity was too enhanced significantly as revealed through in vivo studies [26].

Rajan and Vasudevan 2012 studied the effect of permeation enhancers (Eucalyptus oil) on penetration of ketoconazole in the form of transfersomal gel. The results suggested the better in vitro release in comparison to conventional forms [27].

Gupta et al., 2012 provided evidence through the study that the permeation enhancers provide the better alternate to the conformist forms. The study also revealed the poorly soluble drug sertraline can be easily delivered transdermally using natural permeation enhancers [28].

Tawfeek et al., 2020 formulated the Lornoxicam transfersomes containing sodium deoxycholate. The drug belongs to the family of antiinflammatory drugs and showed poor permeability. The results concluded that the encapsulated formulation showed better permeation along with higher flux and apparent permeability coefficient and superior anti-inflammatory activity compared to non-transfersomal LOR hydrogel and indomethacin gel as a standard NSAID [29].

Aggarwal et al., 2012 carried out the development of transdermal delivery system of olanzapine utilizing natural oils as permeation enhancers. Penetration enhancing the potential of groundnut oil, corn oil and jojoba oil on in vitro permeation of olanzapine across rat skin was studied. The results suggested relative bioavailability of TDDS was $113.6 \%$ as compared to oral administration of olanzapine [30].

Patil and Saragoi 2014 carried out the study of natural products as permeation enhancers. The permeation enhancer proves to be safe, 
non-toxic, pharmacologically inert, non-irritating, and nonallergenic. Moreover, the SAR studies on the used permeation enhancers provided the results of better bioavailability and significantly enhanced activity [31].

Sharma et al., 2010 designed to develop a suitable matrix type transdermal drug delivery system (TDDS) of olanzapine using blends of two different polymeric combinations, polyvinylpyrrolidone (PVP) and ethylcellulose (EC). Vegetable oils (soyabean oil, olive oil, eucalyptus oil) were employed as permeation enhancers. In vitro skin permeation study was also conducted in a modified Franz's diffusion cell which shows that the maximum permeation was with the formulation C3 and it was $768.64 \mu \mathrm{g} / \mathrm{cm} 2$ after $48 \mathrm{~h}$. Optimized formulations were found to be suitable for formulating in terms of physicochemical characteristics and there was no significant interaction noticed between the drug and polymers used [32].

Nan et al., 2018 investigated the enhancement effects of natural transdermal permeation enhancers from Ledum palustre L. var. angustum N. Busch. The outcomes of research recommended that the effectiveness and safety of the natural transdermal permeation enhancers could be improved by understanding their composition and the enhancement mechanisms [33].

\section{CONCLUSION}

From the current review work, the critical roles of the permeation enhancers are being accessible. The permeation enhancers are being available in wide varieties and so many options that the researchers can modify the formulations. The recent advancements in the utilization of the enhancers also suggested the commercial role and the marketed value. Further, the future prospective of the penetration enhancers is still not clear and needs more research to strengthen its economical and marketable value.

\section{FUNDING}

Nil

\section{AUTHORS CONTRIBUTIONS}

All the authors have contributed equally.

\section{CONFLICT OF INTERESTS}

Declared none

\section{REFERENCES}

1. Larregieu CA, Benet LZ. Distinguishing between the permeability relationships with absorption and metabolism to improve BCS and BDDCS predictions in early drug discovery. Mol Pharm 2014;11:1335-44

2. Charalabidis A, Sfouni M, Bergström C, Macheras P. The biopharmaceutics classification system (BCS) and the biopharmaceutics drug disposition classification system (BDDCS): beyond guidelines. Int J Pharm 2019;566:264-81.

3. Ozawa M, Tsume Y, Zur M, Dahan A, Amidon GL. Intestinal permeability study of minoxidil: assessment of minoxidil as a high permeability reference drug for biopharmaceutics classification. Mol Pharm 2015;12:204-11.

4. Tamura S, Ohike A, Ibuki R, Amidon GL, Yamashita S. Tacrolimus is a class II low-solubility high-permeability drug: the effect of P-glycoprotein efflux on regional permeability of tacrolimus in rats. J Pharm Sci 2002;91:719-29.

5. Li ZQ, Tian S, Gu H, Wu ZG, Nyagblordzro M, Feng G, et al. In vitro-in vivo predictive dissolution-permeation-absorption dynamics of highly permeable drug extended-release tablets via drug dissolution/absorption simulating system and $\mathrm{pH}$ alteration. AAPS PharmSciTech 2018;19:1882-93.

6. Tehler U, Fagerberg JH, Svensson R, Larhed M, Artursson P, Bergström CA. Optimizing solubility and permeability of a biopharmaceutics classification system (BCS) class 4 antibiotic drug using lipophilic fragments disturbing the crystal lattice. J Med Chem 2013;56:2690-4.

7. Caldeira TG, Saude Guimaraes DA, Dezani AB, Serra CHDR, de Souza J. In silico and in vitro prediction of gastrointestinal absorption from potential drug eremantholide C. J Pharm Pharmacol 2017;69:1468-76.

8. Tsume Y, Igawa N, Drelich AJ, Amidon GE, Amidon GL. The combination of GIS and biphasic to better predict in vivo dissolution of BCS class IIb drugs, ketoconazole and raloxifene. J Pharm Sci 2018;107:307-16.

9. Liu X, Chen T, Liu X, Chen Y, Wang L. Penetration effect of ostrich oil as a promising vehicle on transdermal delivery of sinomenine. J Oleo Sci 2013;62:657-64.

10. Wang Y, Zhou L, Ling J. Effect of penetration enhancers on the transdermal penetration of sinomenine liposome patch. J Chinese Med Materials 2005;28:567-70.

11. Priborsky J, Takayama K, Nagai T, Waitzova D, Elis J. Combination effect of penetration enhancers and propylene glycol on in vitro transdermal absorption of insulin. Drug Design Delivery 1987;2:91-7.

12. Jampilek J, Brychtova K. Azone analogues: classification, design, and transdermal penetration principles. Med Res Rev 2012;32:907-47.

13. Qian L, Ma Z, Zhang W, Wang Q. Influence of penetration enhancers on in vitro transdermal permeation of $\mathrm{L}$ tethrahydropalmatine. BMC Complementary Altern Med 2011;36:1729-32.

14. Cui LL, Ma YS, Han HX. Enhancing effect of volatile oils of rhizoma zingiberis, flos magnoliae and fructus litseae on permeation of rotundine in vitro. J Chinese Med Materials 2011;34:753-7.

15. Chen HL, Cai CC, Ma JY, Yu ML, Zhao MH, Guo JB, et al. Effect of the dispersion states of azone in hydroalcoholic gels on its transdermal permeation enhancement efficacy. J Pharm Sci 2018;107:1879-85.

16. Ramadon D, McCrudden MTC, Courtenay AJ, Donnelly RF. Enhancement strategies for transdermal drug delivery systems: current trends and applications. Drug Delivery Translational Res 2021;20:1-34.

17. Gunther A, Makuch E, Nowak A, Duchnik W, Kucharski L, Pelech $\mathrm{R}$, et al. Enhancement of the antioxidant and skin permeation properties of betulin and its derivatives. Molecules 2021;26:3435.

18. Ossowicz P, Klebeko J, Janus E, Nowak A, Duchnik W, Kucharski $\mathrm{L}$, et al. The effect of alcohols as cosmetic formulations on the percutaneous absorption and skin retention of ibuprofen modified with l-valine alkyl esters. RSC Adv 2020;10:4172740.

19. Janus E, Ossowicz P, Klebeko J, Nowak A, Duchnik W, Kucharski $\mathrm{L}$, et al. Enhancement of ibuprofen solubility and skin permeation by conjugation with L-valine alkyl esters. RSC Adv 2020;10:7570-84.

20. Bormann JL, Maibach HI. Effects of anatomical location on in vivo percutaneous penetration in man. Cutaneous Ocul Toxicol 2020;39:213-22.

21. Gupta R, Dwadasi B, Rai B. Samir mitragotri effect of chemical permeation enhancers on skin permeability: in silico screening using molecular dynamics simulations. Sci Rep 2019;9:1456.

22. Kala S, Juyal D. Recent developments on natural transdermal penetration enhancers. Int J Pharm Sci Res 2018;9:2190-6.

23. Yang Chen, Peng Quan, Xiaochang Liu, Manli Wang, Liang Fang. Novel chemical permeation enhancers for transdermal drug delivery. Asian J Pharm Sci 2014;9:51-64.

24. Barry BW. Dermatological formulation: percutaneous absorption. Marcel Dekker, New York; 1983.

25. Omar MM, Hasan OA, El Sisi AM. Preparation and optimization of lidocaine transferosomal gel containing permeation enhancers: a promising approach for enhancement of skin permeation. Int J Nanomed 2019;14:1551-62.

26. Loganathan V, Manimaran S, Jaswanth A, Sulaiman A, Shivaprasadha Reddy MV, Kumar BS, et al. The effects of polymers and permeation enhancers on releases of flurbiprofen from gel formulations. Indian J Pharm Sci 2001;63:200-4.

27. Rajan R, Vasudevan DT. Effect of permeation enhancers on the penetration mechanism of transfersomal gel of ketoconazole. J Adv Pharm Technol Res 2012;3:112-6.

28. Gupta A, Aggarwal G, Singla S, Arora R. Transfersomes: a novel vesicular carrier for enhanced transdermal delivery of 
sertraline: development, characterization, and performance evaluation. Sci Pharm 2012;80:1061-80.

29. Tawfeek HM, Abdellatif AAH, Abdel-Aleem JA, Hassan YA Fathalla D. Transfersomal gel nanocarriers for enhancement the permeation of lornoxicam. J Drug Delivery Sci Technol 2020;56A:101540.

30. Aggarwal G, Sanju D, Hari Kumar LS. Natural oils as skin permeation enhancers for transdermal delivery of olanzapine: in vitro and in vivo evaluation. Curr Drug Delivery 2012;9:172-81.

31. Patil UK, Saraogi R. Natural products as potential drug permeation enhancer in transdermal drug delivery system. Arch Dermatol Res 2014;306:419-26.
32. Sharma S, Aggarwal G, Dhawan S. Design and evaluation of Olanzapine transdermal patches containing vegetable oils as permeation enhancers. Der Pharm Lett 2010;2:84-98.

33. Nan L, Liu C, Li Q, Wan X, Guo J, Quan P, et al. Investigation of the enhancement effect of the natural transdermal permeation enhancers from Ledum palustre L. var. angustum N. Busch: mechanistic insight based on interaction among drug, enhancers and skin. Eur J Pharm Sci 2018;124:105-13. 